\title{
Significancy and Subtancy of Civil Suit Compensation in Corruption Case where the Defendant was Acquitted by Judge
}

\author{
Alfon $^{1}$, Suhariningsih ${ }^{2}$, Bambang Sugiri ${ }^{3}$, Prija Djatmika ${ }^{4}$ \\ 1,2,3,4 Doctor of Law Study Program, Faculty of Law, Universitas Brawijaya, Malang, Indonesia \\ alfonalfon24@gmail.com
}

\begin{abstract}
The spirit of Article 32 paragraph(2) of UU 31/1999 jo. UU 20 /2001 means the country can use its right to a civil action for compensation for financial loss recovery state. The rationale for setting lawsuit replace losses in the article that indicates that in order to restore the country's financial losses due to corruption is not enough only in lean to the norms of criminal law. If the UU 31 / 1999 jo. UU 20/2001 categorized as Criminal Laws, then the regulation of a civil lawsuit in the Law, shows that a Prevailing Law may contain aspects of both criminal law and civil law. The study is the study of law by using the approach of Legislation, conceptual and historical approach. The results were obtained from studies of this are: 1) The specificity handling of corruption judging from the way the settlement; 2) The meaning and essence of civil suit for damages in the enforcement of the law on corruption. The civil lawsuit instrument is intended to maximize the return on state financial losses, because criminal efforts do not always succeed in recovering the entire state financial losses. The limitations of criminal law make criminal law instruments not the only one to solve the problem of returning state finances due to criminal acts of corruption.
\end{abstract}

Keywords civil law; lawsuit civil; compensation; corruption

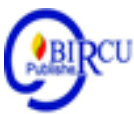

\section{Introduction}

Corruption is considered a form of administrative crime that hinders development efforts to achieve people's welfare. In addition, the criminal act of corruption is an act of fraud against legal norms and other social norms (Danil, 2014). In the perspective of criminal law, corruption is classified as a very dangerous form of crime, both against the community and against the nation and state. State financial losses and the economy of the State is the real result of the justification does the criminalization of various forms of corrupt behavior in the policy Regulations - Invitation criminal. However, the loss of public trust in the government of a country is actually a far greater and more dangerous consequence than just a loss from financial and economic sources alone.

Corruption has caused damage to various aspects of public life, the Nation. So, the efforts to prevent and eradicate criminal acts of corruption need to be carried out continuously. Policy or efforts to combat crime are essentially an integral part of community protection efforts and efforts to achieve community welfare (Hikmah \& Sopoyono, 2019). Recognizing the complexity of the problem of corruption in the midst of a multi- dimensional crisis and the real threat that will inevitably occur as a result of this crime, the criminal act of corruption can be categorized as a national problem that must be dealt with seriously through 
a balance of firm and clear steps with involve all the potential that exists in society, especially the government and law enforcement officials. The quality, quantity and intensity of development of such corruption was not enough to be handled by ordinary means, but must in ways extraordinary, that is based on the principles set forth in the Law 31 / 1999 jo. Law 20 / 2001.

Completion of corruption that led to the financial loss State under Law 31 / 1999 jo. Law 20 / 2001, oriented towards recovering state financial losses, either by means of criminal law and civil law means. Crime against financial losses of the state of law or abuse of power, bribery offense groups, groups in post evasion offense, offense of extortion in office, act violations, offenses relating to interest on procurement, and gratuities (Russell, 2015) . Seeing some weaknesses in law enforcement of corruption through criminal channels, especially recovery of state financial losses in the form of asset confiscation, another route is needed that can be used as an alternative in recovering state losses, namely through civil suit (Zebua et al., 2008), one of which is a lawsuit replace losses are regulated in Article Article 32 Paragraph (2) of Law 31 / 1999 jo. Law 20 / 2001, which states: " The verdict is Free in corruption cases do not abolish the right to demand financial loss to the state ".

When analyzed the norms of Article 32 paragraphs (2) of Law 31 / 1999 jo. Law 20 / 2001, then the spirit of this article is that the state can use its right to a civil action for compensation for financial loss recovery state. This provision gives the authority to the State Attorney or the agency that has been injured to file a civil claim for compensation against the accused. Thus, through the civil suit for compensation, the State Attorney General can continue to file a lawsuit due to a criminal act of corruption if the defendant is acquitted and no elements of a criminal act are found but there is a real loss to the State.

As a norm of law, the existence of Article 32 paragraph (2) of Law 31 / 1999 jo. Law $20 / 2001$ has the intent and purpose that is about to be achieved by forming Act. the meaning of the concept of state economic loss becomes a problem because even though the concept of the state economy has been explained in the General Explanation of the PTPK Law, it is still considered not applicable. In the practice of law enforcement on corruption, there are almost no decisions that state a defendant has committed a criminal act of corruption that is detrimental to the country's economy (Firmansyah, 2020). A civil suit for compensation is possible in a criminal act of corruption, philosophically, as a matter of seeking the basis of regulatory legitimacy or justification for the state in formalizing it as a norm. The basis for the legitimacy of a civil suit in a criminal act of corruption lies in the incidence of losses, in this case state finances that must be returned. The repayment of the corrupted state finances was carried out by way of civil litigation.

Based decline of explanation at the top, then it becomes the issue of law which is attractive to be studied related to the meaning and nature of claim civil compensation losses in Article 32 paragraph (2) of Law 31/1999 jo . Law 20/2001. The rationale for regulating civil suits in Law 31/1999 jo. Law 20/2001 indicates that corruption is an extraordinary crime which requires extraordinary methods to handle it.

According to Purba (2019) An action is referred to as a criminal act (strafbaar feit), then the elements or elements that must be present in a criminal act must have behavior and the consequences of the action, things or circumstances that accompany the action. Zulyadi (2020) states that Corruption is a specific criminal act which is regulated outside of the Criminal Code Corruption is a criminal act which involves bribery manipulation and acts against the law that are detrimental or can harm the country's finances or the country's economy, detrimental to the welfare or interests of the people / general. 


\section{Research Method}

This research is a legal research with a qualitative paradigm. The legal materials used are primary, secondary, and tertiary legal materials which are analyzed using normative / prescriptive analysis. The approach method used in this research is the normative juridical approach as the main approach, and is supported by the civil law approach. Based on the normative juridical approach method, the research method refers to the legal norms contained in statutory regulations which in this case relate to the problem of corruption suits in civil law (Abdul Kadir, 2015).

\section{Discussion}

\subsection{The Specificity of Handling Corruption Crime in Terms of Its Resolution}

Settlement of criminal acts of corruption that cause losses to state finances according to Law 31/1999 jo . Law 20/2001, is oriented towards recovering state financial losses. Therefore, the pattern of law enforcement acts of criminal corruption lacks specificity compared with other crimes in Indonesia. As for the specificities of the handling and settlement of criminal acts of corruption, namely:

\section{a. Criminal Charges}

Settlement of state financial losses through criminal law means can be carried out by imposing cumulatively on the principal crimes with fines, unless the object value of the criminal act of corruption is less than RP. 5,000,000.00 (five million rupiah) which deviates from the imposition of general penalties. In addition, there are also additional new types of punishment as regulated in Article 18 paragraph (1) of Law 31/1999 jo. Law $20 / 2001$ is not known in general crimes and imposes imprisonment for perpetrators of corruption who cannot pay additional penalties in the form of compensation for state losses as regulated in Article 18 paragraph (3) of Law 31/1999 jo. Law 20/2001.

Through this line of criminal charges, confiscation of assets resulting from corruption can also be carried out provided that the public prosecutor must be able to prove the defendant's guilt in committing the corruption crime. The confiscated assets must also be assets resulting from acts of corruption. Thus the concept, called the confiscation of assets based on guilt of the accused (Conviction Based Asset forfeiture), it means the deprivation of an asset to corruption is highly dependent on the successful investigation and prosecution of that criminal cases (Joseph, 2013). This concept is contained in Article 39 and Article 46 paragraph (2) of Law 8/1981.

Article 38B Paragraph (2) of Law 31/1999 jo. Law 20/2001 states:

Confiscation of assets which is the result of a criminal act of corruption also includes if the defendant is unable to prove that the assets referred to as being obtained are not due to a criminal act of corruption, so that the assets are deemed to have been obtained from a criminal act of corruption and the judge is authorized to decide all or part of the assets deprived for the State.

If it is detailed that the confiscation of assets from the line of criminal prosecution is carried out through a trial process in which the judge in addition to imposing the basic sentence can also impose additional punishment. Additional punishments can be imposed by the judge in certainty that correlates with the return of state financial losses through confiscation of assets. The expropriation of these assets can be in the form of (Ibid, nd). 
1. Confiscation of movable property that is tangible or intangible or immovable property that is used for or obtained from a criminal act of corruption, including the company owned by the convict where the criminal act of corruption is committed, as well as the price of the goods that replace the goods; (Article 18 Paragraph (1) letter a Law 31/1999 jo. Law 20/2001).

2. Payment of replacement money in an amount equal to the assets obtained from the criminal act of corruption; (Article 18 paragraph (2), (3) Law 31/1999 jo. Law 20/2001).

3. Article 38 paragraph (5) and (6) Law 31/1999 jo. Law 20/2001 that can be done deprivation of possessions to corruption that the criminal case could not continue the legal process because the defendant died. After the evidentiary process and from the examination of evidence in court there is sufficiently strong evidence that the person concerned has committed a criminal act of corruption, the judge on the prosecution's demands determines the confiscation of goods that have been confiscated and a ruling of confiscation.

\section{b. Civil Charges}

Seeing several weaknesses in law enforcement of corruption through criminal channels, especially recovery of state financial losses in the form of confiscation of assets, another route is needed that can be used as an alternative in recovering state losses, namely through civil suit. This is regulated in the provisions of Article 32 paragraph (1) and Paragraph (2), Article 33, and Article 34 of Law 31/1999 jo. Law 20/2001, namely:

1. Civil lawsuit for recovering real state financial losses because after an investigation is found that there is insufficient evidence, as provided for in Article 32 paragraph (1);

2. Civil suit was caused due to an acquittal, while in fact there was a loss in state finance, as regulated in Article 32 paragraph (2);

3. Civil suit in the event that the suspect dies at the time of the investigation, while in fact there has been a loss of state finances, as regulated in Article 33;

4. Civil lawsuit in the event that the defendant dies during a court hearing, while in fact there has been a loss of state finances, as regulated in Article 34;

5. Civil litigation against a criminal act of corruption that has permanent legal force, but there are still assets suspected of originating from a criminal act of corruption that has not been subject to confiscation for the state, as regulated in Article 38C.

\section{c. The Demands of the Treasury and the Demands of Civil}

Settlement of losses financial state in the dimensions of the legal administration of the State, in principle, oriented on recovery of losses financial state, and can be enforced by the cumulative to sanction another, which sanction criminal, administrative and civil cases (Suhariyono AR, 2009). This is seen as regulated in:

1. Law 17 / 2003;

In- Law $17 / 2003$, the treasury demands and the demands of civil only regulated in one article, namely Article 35, which consists of four verses. But keep in mind is that Article 35 paragraph (4), "The provisions concerning the settlement of losses the state is set in the legislation regarding treasury of the state ". Quite clear that on completion of the loss to the state by the Law 17 / 2003 will be regulated separately in the legislation on the state treasury.

Moreover, in Article 1 of Law $17 / 2003$, which set the terms of what is stipulated in Law 17/ 2003, there was no understanding of the demands of the treasury and claims for damages. Similarly, in the explanation of Article of Law 17/2003 only stated quite 
clearly. However, in the general explanation, it is explained that "Apart from that it is necessary to emphasize the universally applicable principle that anyone who is authorized to receive, keep, and pay or deliver money, securities or state property is personally responsible for all deficiencies that occur in the arrangement. The obligation to compensate the state's financial managers is an element of reliable internal control.

2. Law 1 / 2004;

As mandated by Article 35 paragraph (4) of Law 17/ 2003 "provisions regarding the settlement of state losses set in the legislation on the state treasury", then the following is discussed is the Law 1/2004. In the structure of Act $1 / 2004$, there were It is found that the definition of treasury demands and civil charges is the definition of state / regional losses as regulated in Article 1 point 22, "State / regional losses are shortages of money, securities, and goods, which are real and definite as a result of acts against the law, deliberately or negligently".

Furthermore, in the general description of State Loss Resolution number 6, Law 1/2004 affirmed "to avoid financial losses countries / regions as a result of an unlawful act or omission of a person, in the law of this state treasury set the solution loss provisions on country / region". Therefore, in Act 1 / 2004 is confirmed that:

Every state / regional loss caused by an illegal act or someone's negligence must be compensated by the guilty party. With the settlement of these losses, the state / region can be recovered from the losses that have been incurred. In this connection, each head of the state ministry / institution / head of the regional apparatus work unit is obliged to immediately file a civil suit after knowing that losses have occurred in the relevant ministry / institution / regional apparatus work unit. The state / regional compensation is imposed on the treasurer by the Supreme Audit Agency, while the imposition of state / regional compensation for non-civil servants is determined by the minister / head of institution / governor / regent / mayor. Treasurers, civil servants who are not treasurers and other officials who have been appointed to compensate state / regional losses may be subject to administrative witnesses and / or criminal sanctions if they are proven to have committed adminis trative and / or criminal violations.

Law $1 / 2004$, the treasury demands and the demands set civil, as set out in Chapter XI of settlement of losses to the state / region from Article 59 to Article 67.

3. Law 15 / 2004

Law 15/2004 was the law designated by Act 1/2004 for the imposition of restitution countries / regions of the treasurer as provided for in Article 62 paragraph (3). Arrangements regarding the demands of the treasury and the demands of civil in Law 15 / 2004 set out in Chapter V Imposition of Indemnity State, Article 22 paragraph (1), paragraph (2), paragraph (3), (4) and (5) and Article 23 paragraph (1) and paragraph (2).

Arrangements regarding the imposition of damages against the state treasurer referred by the Law 1/2004 and the Law 15/2004 were only set with two chapters. The author understands that this reference was minimal settings are not comparable with what you desire Law 1/2004. Supposedly indemnification arrangements regarding the imposition of the state of the treasurer is set wider in Law 15 / 2004.

Government Employees treasurer or officer is not another may be subject to prosecution for damages the country / region where conducted unlawful actions or omissions directly cause losses to the state / region, making it mandatory to replace those losses. The claim for compensation aims to recover state / regional losses (Juliani, 2017). 
Which should be a concern of the two articles is Article 22 paragraph (4) of Law 15/2004 that: "The procedure for the settlement of restitution countries / regions against the treasurer set by the CPC after consultation with the government".

3. Law 15 / 2006;

Article 10:

- BPK assess and / or specify the amount of damages the state were caused by the actions against the law either deliberate or negligent were performed by the treasurer , manager of Agency Enterprises Owned Country/Entity Enterprises Owned Regions, and institutions or bodies other organized management of financial state;

- Ratings losses financial state and / or determination of the parties are obliged to pay compensation losses as referred to in paragraph (1) determined by the decision the $\mathrm{CPC}$;

- To guarantee implementation of payment compensation loss, the CPC is authorized to monitor:

- Completion replace losses countries / regions are defined by the Government of the employees state instead treasurer and officials of the other;

- Implementation of the imposition replace losses countries/regions to the treasurer, manager of Agency Enterprises Owned Country / Entity Enterprises Owned Regions, and institutions or bodies other manage finances the state that has been set by the $\mathrm{CPC}$; and

- Implementation of the imposition replace losses countries/regions are determined by the decision of the court which has to have the power of law remains.

- The results of the monitoring, as referred to in paragraph (3) notified in writing to the DPR, DPD, and DPRD in accordance with the authority of her.

Technically, the authority of the CPC in the complete loss of finances of State regulated in Regulation BPK No. 3 Year 2007 on Procedures for the Settlement Change Losses Countries Against Treasurer. Government Employees is not the treasurer or other official may be subject to prosecution for damages the country / region where conducted unlawful actions or omissions directly cause losses to the state / region, so shall indemnify the (Juliani, 2017).

BPK as an independent and independent audit agency in conducting audits is based on the principles of accountability, transparency, accountability, and professionalism as a manifestation of the implementation of good governance principles in Indonesia so as to create good governance where BPK in conducting audits can expose $\mathrm{KKN}$ practices and save state money (Raba ', 2017).

\subsection{The Meaning and Essence of Lawsuit Civil Switch Losses Law Enforcement Corruption}

Civil suits to recover state financial losses were historically first regulated in Army Chiefs of Staff Central Warlord Regulation No. Prt / Peperpu / 013/1958 (Pancaningrum, 2015). Army Chief of Staff Central Warlord Regulation No. Prt / Peperpu / 013/1958 contains new matters relating to the formulation of criminal acts of corruption that are not specified in other regulations. Article 1 of the Army Central War Ruler Regulation distinguishes corruption into two, namely (1) criminal corruption and (2) other acts of corruption (Toruan, 2014).

Corruption is regulated in the provisions of Article 2 of the Army Chief of Staff's Central War Ruler Regulation No. Prt / Perpu / 013/1958, which reads: 
1. An act of a person who with or because of committing a crime or violation enriches himself or another person or an agency which directly or indirectly harms the finances or economy of the state or region or causes financial loss to an agency receiving assistance from state or regional finances or agencies. Other laws that use capital and concessions from the community;

2. An act which with or because of committing a crime or violation enriches oneself or another person or a body and which is committed by abusing one's position or position;

3. The crimes listed in Article 41 to Article 50 of this Central Warlord Regulation and in Article 209, Article 210, Article 418, Article 419, and Article 420 of the Criminal Code.

As for what is meant by other acts of corruption in Article 3 of the Army Chief of Staffs Central War Ruler Regulation No. Prt / Peperpu / 013/1958 (Amiruddin, 2012), stated:

1. An act of a person who with or because of committing an illegal act enriches himself or another person or an entity that directly or indirectly harms the state or regional finances or causes financial loss to an entity receiving assistance from state or regional finances or other legal entities. Who use capital or concessions from the community;

2. An act of someone who with or because of committing an illegal act enriches himself or another person or a body and is committed by abusing his position or position.

Corruption is an extraordinary crime, so eradicating it must be carried out with extraordinary measures, as well as using extraordinary instruments (Yuhermansyah \& Fariza, 2017 ) . Other acts of corruption are essentially actions against the law that harm state finances, regional finances, or financial institutions that receive assistance from the state. The legal action is civil in nature, therefore it is not threatened and not subject to punishment.

After the birth of Law 24 / Prp / 1960 which replaced the War Rulers Regulation No. Prt / Perpu / 013/1958 civil suit no longer adhered to. A civil suit for a new criminal offense be raised with the birth of Law 31 / 1999 jo Law 20 / 2001 as provided for in Article 32 paragraph (1) and (2), Article 33, 34 and Article $38 \mathrm{C}$ Act PTPK.

Elucidation of Article 38 C of Law 31 / 1999 jo Law 20 / 2001, explains:

The objective underlying the civil suit is to recover state financial losses due to corruption, namely to fill the sense of justice in society. Sense of justice emphasized in this explanation because it found many perpetrators of corruption are hide treasure believed to have originated from corruption offenses. Civil suits are thus carried out to fill the sense of justice in society. This is because if it is not done, it will hinder national development, as well as growth and the continuity of national development which demands high efficiency.

In line with this objective, Indonesia has ratified the Convention against Corruption in 2003, which emphasizes the prevention or protection in financial losses or the economy of the country. Interests protected by Law 31 / 1999 jo Law 20 / 2001, that the "financial economy of the state" (Amiruddin, 2012). When compared with the Book of the Law Criminal more to protect the interests of individuals, the Law 31 / 1999 jo Law 20/2001 put more emphasis on the interests of the state or public interests. Corruption in this context is linked to the occurrence of losses to the country's finances or economy.

Returns to state financial losses or the country's economy are significant for the following reasons (Yanuar, 2007): 
1. First, based on data on state financial losses, it is appropriate to call Indonesia a victim of corruption;

2. Second, the funds or assets that were corrupted are the assets of the Indonesian state which should have been earmarked for development in an effort to increase the prosperity and welfare of the Indonesian people. The criminal act of corruption has resulted in the loss of the opportunity for the Indonesian people to enjoy their rights, and has put the majority of the people living below the poverty line;

3. Third, the state has an obligation to protect and create welfare for its people through the achievement of alternative sources of funding. One of the sources of funding must be taken from funds or assets resulting from criminal acts of corruption;

4. Fourth, efforts to recover assets have a preventive meaning (prevention) and a repressive meaning (eradication). The meaning of preventive lies in disclosing to the public that there is no safe place in the world for perpetrators of corruption to hide assets resulting from corruption. Meanwhile, the meaning of repressive lies in the convictions of the perpetrators of corruption;

5. Fifth, Indonesia has ratified the 2003 United Nations Anti-Corruption Convention on the Return of Assets, so that there is an international legal basis for carrying out international cooperation in efforts to recover assets resulting from criminal acts of corruption.

One way to recover state financial losses due to criminal acts of corruption is through civil measures. The accused and convicted possession of property to recover state financial losses incurred, by preparing formal evidence and arguments known as the burden of proof in order to achieve the goal of returning state assets through a civil suit in a criminal act of corruption (WIBOWO, 2017). Thus, civil suits are intended to maximize the return on state finances, because criminal measures do not always succeed in recovering total losses to state finances. Among other things, this fact can be described based on the condition that there is still state money that is owned by the convict of corruption, apart from that which was confiscated based on the decision of the criminal court.

Corruption Eradication, in fact, always involves two or more perpetrators, especially involving officials and the private sector. The two parties work together to achieve the same goal to gain mutual benefits against the law. Criminal acts that involve two people and are carried out jointly in the criminal act of corruption are identical to the form of participation between officials and the private sector as referred to in Article 55 paragraph (1) one of the third form of the Criminal Code. In fact, the position and quality between officials and the private sector are not the same. Corruption in the form of abuse of authority or against the law in one's position is impossible to be carried out by persons or parties who do not have a position. This Corruption Crime will not occur if there are no perpetrators who, in fact, do not have a position or authority. Is it possible that an actor who does not have the quality of an official can be equated with an actor who has a position and / or authority? Can inclusion in the form of participation in Article 55 of the Criminal Code can be applied to offenses involving officials and the private sector (Maharani, 2020).

In principle, when the court decision was final and binding, no further effort criminal law that can be taken, put the civil suit as a primary procedure in the return of the country's financial losses, in addition to deprivation made through criminal procedure. A civil lawsuit is possible in a criminal act of corruption which is philosophically an issue of seeking the basis for regulatory legitimacy or justification for the state in formalizing it as a norm. The basis for the legitimacy of a civil suit in a criminal act of corruption lies in 
the incidence of loss, in this case the state finances that must be returned. The return of the compted State finances is carried out by way of a civil lawsuit.

Thealternatively directed from two sources (Iskandar, 2019):

1. From the proceeds of corruption that have become part of the wealth of the defendant or suspect;

2. Replaced with the assets of the convict, defendant or suspect, even though he has no results of corruption. Corruption carried out in this case benefits another person or a corporation and the convict, defendant or suspect does not take advantage of the state finances that are being corrupted for himself.

Based on the description above, the possibility of setting a civil lawsuit in the Law 31 / 1999 jo Law 20 / 2001, were based reasons as follows:

1. Settlement of criminal cases of corruption does not always succeed in recovering state financial losses, at least in certain circumstances. The limitations of criminal law make criminal law instruments not the only one to solve the problem of returning state finances due to criminal acts of corruption;

2. Corruption is an extraordinary crime involving power and state losses, so the handling is done in an extraordinary way, that is, in addition to the criminal route, it is also carried out through the civil route;

3. The purpose of regulating a civil suit is intended to fill the public's sense of justice against the perpetrators of criminal acts of corruption who hide the proceeds of corruption, than a civil suit is regulated to maximize the return of state finances.

Another effort from law enforcement to increase awareness and understanding of the law for the public, especially in eradicating corruption, is repressive actions. A repressive approach in the form of prosecution and handling of corruption crimes is carried out professionally and proportionally. Preventive measures, in the form of criminal sanctions against criminals, which prioritize the aspects of balance of interests and restoration of situations caused by law violations (Tampubolon, 2016).

\section{Conclusion}

The essence of the need for tort civil in case of acts of criminal corruption which accused him cut free by a judge that is contained meaning that very powerful to fill a sense of justice as a result of the action against the law that made the defendant. The civil lawsuit instrument is intended to maximize the return on state financial losses, because criminal efforts do not always succeed in recovering the entire state financial losses. The limitations of criminal law make criminal law instruments not the only one to solve the problem of returning state finances due to criminal acts of corruption. In addition, the criminal act of corruption is an extraordinary crime, which involves power and state losses, so how to handle it is done in an extraordinary way, namely in addition to the criminal route it is also carried out through the civil route. In principle, that the right of the State shall be returned to the State, to be used for the benefit of the welfare of the people, so that when the court decision was final and binding, and no criminal legal action that can be taken to put the lawsuit civil as the main procedure in the return of the country's financial losses. 


\section{References}

Abdul Kadir, M. (2015) 'Hukum Dan Penelitian Hukum.', Bandung : PT. Citra Aditya Bakti.

Amiruddin, A. (2012). Analysis Of Corruption Eradication Patterns In Government Procurement Of Goods / Services. Indonesian Journal of Criminology.

Danil, E. (2014). Corruption (Concept, Crime, and Eradication). Rajagrafindo Persada.

Eka Iskandar, Principle Of Returning Corruption Results, Was Published In The Artilek Legal Opinion Legal Ideas Online Media, Https://Gagasanhukum.Worpress.Com , Accessed On 19 May 2019.

Elwi Danil , Corruption ( Concept , Acts Criminal , And Eradication ) , ( Jakarta : Rajagrafindo Persada, 2014 ).

Firmansyah, Ra (2020). The Concept Of State Economic Loss In The Corruption Crime Law. Jurist-Diction. Https://Doi.Org/10.20473/Jd.V3i2.18211

Hikmah, H., \& Sopoyono, E. (2019). Death Criminal Sanction Formulation Policy Against The Criminals Of Corruption Based On Justice. Journal of Indonesian Legal Development. Https://Doi.Org/10.14710/Jphi.V1i1.78-92

Iskandar, E. (2019). The Principle Of Returning The Assets From Corruption. Online Media Of Artilek Legal Opinion Ideas, Https://Gagasanhukum. Worpress.Com.

Juliani, H. (2017). Settlement Of Demands For State / Regional Losses Against Non-Fuel State Employees And Other Officers. Law Reform. Https://Doi.Org/10.14710/Lr.V13i2.16158

Maharani, USA (2020). Inclusion in The Offense Of Position In Corruption Crimes. In Jurist-Diction.

Muhammad Yusuf, Seizing The Assets Of Corruptors (Solution To Eradicate Corruption In Indonesia), (Jakarta: Kompas, 2013).

Pancaningrum, Rk (2015). Humanism In Indonesia's Corruption Laws. Journal Of Legal Communication (Jkh). Https://Doi.Org/10.23887/Jkh.V1i2.6106

Purba, I.G., and Syahrin, A. (2020). Demand against Law and Using Authority in Corruption Criminal Action. Budapest International Research and Critics InstituteJournal (BIRCI-Journal) Vol 2 (4): 194-206

Purwaning M. Yanuar, Return Of Corruption Proceeds Based On The 2003 UN Convention Against Corruption In The Indonesian Legal System, (Bandung: Alumni, 2007).

Raba ', Mr (2017). The Role Of The Financial Audit Agency (Bpk) In Conducting An Examination Of State Financial Management To Make Good Governance According To The Law No. 15 Of 2006. Lex Crimen.

Republic Of Indonesia, Law No. 31 Year 1999 , State Gazette Of The Republic Of Indonesia Year 1999 Number 140.

Republic Of Indonesia, Law No. 20 Of 2001 Concerning The Enforcement Of Corruption Crimes, State Gazette Of The Republic Of Indonesia Of 2001 Number 134.

Republic Of Indonesia, Law No. 17 of 2003 Concerning State Finance, State Gazette Of The Republic Of Indonesia Tanun 2003 Number 47.

Republic Of Indonesia, Law No. 1 of 2004 Concerning State Treasury, State Gazette of the Republic Of Indonesia Of 2004 Number 5.

Republic Of Indonesia, Law No. 15 Of 2004 Concerning Audit Of Management And Accountability Of State Finances, State Gazette Of The Republic Of Indonesia Of 2004 Number 66. 
Republic of Indonesia, Law No. 152006 about Audit of the Republic Of Indonesia, the State Gazette of the Republic Of Indonesia Year 2006 No. 85.

Russel, B. (2015). Corporate Responsibility in Corruption in the Procurement of Government Goods and Services in the Construction Sector. Journal of Legal Research.

Suhariyono Ar. (2009). Determination of Criminal Sanctions In One Law. Indonesian Legislation.

Tampubolon, Sm (2016). The Role of the Government in the Efforts to Eradicate Corruption In Relation To Law No. 32 of 2004. Lex Et Socieatatis.

Toruan, Hdl (2014). Corporate Corruption Criminal Responsibility. Journal of Rechts Vinding: Media of National Law Development. Https://Doi.Org/10.33331/Rechtsvinding.V3i3.33

Wibowo, D. (2017). Return of State Assets through Civil Lawsuits in Corruption Crimes. Legal Opinion.

Yanuar, Pm (2007). Return Of Corruption Proceeds Based On The 2003 Un Convention Against Corruption In The Indonesian Legal System . Alumni.

Yuhermansyah, E., \& Fariza, Z. (2017). Death Penalty In The Corruption Crime Act (Zawajir And Answer Theory Study). Legitimation: Journal Of Islamic Criminal Law And Politics . Https://Doi.Org/10.22373/Legittim. V6i1.1848

Yusuf, M. (2013). Seizing The Assets Of Corruptors (Corruption Eradication Solution In Indonesia). Compass.

Zebua, Frp, Jauhari, I., \& Siregar, T. (2008). The Responsibilities Of Corruption Criminal Actors And Their Heirs In The Payment Of Compensation Money For State Financial Losses In Terms Of Civil Law Aspects. Mercatoria Journal.

Zulyadi, R. (2019). Judge's Role in Court to Eradicate Corruption According to Law Number 20 in 2001 (Study of Decision 16/PID.SUS.K/2011/PN.MDN). 